\title{
Trace Metal Contamination in Estuarine Fishes from Vitória Bay, ES, Brazil
}

\author{
Jean-Christophe Joyeux $^{1 *}$, Edmar Augusto Campanha Filho ${ }^{1,2}$ and Honério Coutinho de \\ Jesus $^{2}$ \\ ${ }^{I}$ Departamento de Ecologia e Recursos Naturais; Universidade Federal do Espírito Santo; Av. Fernando Ferrari, \\ s/n; Goiabeiras; 29060-900; joyeux@npd.ufes.br; Vitória - ES - Brazil. ${ }^{2}$ Departamento de Química; Universidade \\ Federal do Espírito Santo; Av. Fernando Ferrari, s/n; Goiabeiras; 29060 -900; Vitória - ES - Brazil
}

\begin{abstract}
Muscular tissue from wild-caught mullet (Mugil spp.) and snook (Centropomus spp.) was analyzed by atomic absorption spectrometry to determine muscle contamination levels for cadmium, chromium, copper, lead and zinc and evaluate risks to human health associated with seafood consumption. Fishes were captured by subsistence fishermen in Vitória Bay, a Brazilian tropical estuary with numerous outfalls of untreated industrial and residential sewage. Based on the premisses that subsistence fisherman and local consumer show weak (culinary or other) preferences within the taxa studied, analyses were conducted and results are reported for genera. Snook cadmium, chromium, copper and zinc concentrations were positively correlated with size or weight. Mullet chromium concentration decreased with size. Cadmium and lead were higher and zinc lower in mullet than in snook. Summer cadmium and lead concentrations were higher than in winter. Chromium presented concentrations consistently over the legal Brazilian limit for seafood. However, the greatest health concern was probably related to lead concentration, especially in respect to consumption by young children.
\end{abstract}

Key words: Estuary, $\mathrm{Cd}, \mathrm{Cr}, \mathrm{Cu}, \mathrm{Pb}, \mathrm{Zn}$, Snook, Mullet

\section{INTRODUCTION}

Trace metals are natural components of the hydrosphere and many are necessary, in minute quantities, for the metabolism of organisms (e.g., arsenic, copper, iron, molybdenum, tin, etc.) (Ward, 1995). However, elevated concentrations in tissues induce toxicity through interference with enzymatic activity, among others (Ward, 1995). In some cases, the difference between deficiency and excess (toxic) levels may be as small as a few $\mu \mathrm{g}$ $\mathrm{g}^{-1}$.(Plant et al., 2001). Several metals, such as cadmium, mercury and lead, are considered highly toxic (Demayo et al., 1980; Demayo, 1981; FDA, 1993a and 1993b). Those do not normally participate to metabolism and, at least in humans, are accumulated throughout the entire life of an individual.

Industrial development and urban expansion frequently are cause to a rise in heavy metal levels in the environment (Rainbow, 1985). Sources of anthropogenic contamination for the aquatic environment include urban sewage (arsenic, chromium, copper, manganese, nickel), biomass combustion (arsenic, mercury, selenium), metal processing (cadmium, nickel, lead, selenium, chromium, molybdenum, antimony, zinc), and seepage from refuse deposits (arsenic, manganese,

\footnotetext{
* Author for correspondence
} 
lead) (Nriagu and Pacyna, 1988). For obvious reasons, acute poisoning of aquatic organisms has been intensely studied (e.g., Mance, 1987). Longterm and in situ comparison studies (e.g., DelValls et al., 1998; Chang et al., 1998) clearly demonstrated the relation between sediment contamination and reduced health of both benthic and demersal fish. Metals are potentially susceptible to bioaccumulation and biomagnification, i.e., absorption from the inorganic compartments of the environment and transmission from lower to higher levels in the food chain (e.g., Blackmore, 2000). Such processes, well demonstrated for mercury (Smith and Smith, 1973), may heavily impact on top predators (including humans) through chronic poisoning. Assimilation efficiency and accumulation of metal from ingested food are dependent upon biological factors as diverse as taxa-specific digestive physiology and metal distribution in preys, among numerous others $(\mathrm{Ni}$ et al., 2000). Metals are further regulated by metallothioneins and others metal binding-proteins (Chang et al., 1998).

Fishing in estuaries is a widespread activity (Joyeux and Ward, 1998). High fishing yields per unit area result from high primary productivity (Nixon, 1982), rapid growth and high survival of target species (Laegdsgaard and Johnson, 2000). Vitória Bay, a polluted Brazilian estuary, is no exception. However, no fishery statistics are available. The most destructive gears (e.g., otter trawl) have been outlawed, although they are still in use, and the other gears are utilized by unlicensed part-time and subsistence fishermen. A previous study has shown that the mussel Mytella guyanensis and the oyster Crassostrea rhizophorae present elevated contamination levels for zinc and chromium (Saraiva, 2000), and there are strong concerns that other biotic compartments are contaminated as well. In the bay, top piscivores are represented by predatory fishes (essentially snooks, snappers, and moray eels), piscivorous birds (essentially egrets and herons, but also kingfishers), and man. According to the local population, top mammalian carnivores such as porpoises and dolphins have long disappeared from the bay.

The present work aimed at determining the concentrations of the trace metals cadmium $(\mathrm{Cd})$, chromium $(\mathrm{Cr})$, copper $(\mathrm{Cu})$, lead $(\mathrm{Pb})$ and zinc $(\mathrm{Zn})$ in the comestible parts of locally commercialized and subsistence fish from Vitória
Bay to evaluate health risks linked to fish consumption. The specific status is of reduced importance for both subsistence fisherman and local consumer in the taxa studied. Thus, instead of using species, the study focused on two genera of detritivorous and carnivorous fishes and emphased the detection of size-concentration relationships and seasonal variability that could affect health risk

\section{MATERIALS AND METHODS}

The estuarine system of Vitória Bay is located around the island capital of the state of Espírito Santo, Brazil $\left(20^{\circ} 19^{\prime} \mathrm{S}\right.$ and $\left.40^{\circ} 20^{\prime} \mathrm{W}\right)$ (Fig. 1). Waters from various tributaries mix with oceanic waters entering through the two channels Canal do Porto and Canal da Passagem, and with urban and industrial sewage generated by more than one million inhabitants. Less than 30\% sewage undergoes primary treatment. The climate is typically tropical with a dry winter and a wet summer. Seasonal conditions directly influence the physico-chemical caracteristics of the water. In the central portion of the bay, temperature and salinity were $27.4^{\circ} \mathrm{C}$ and 26.6ppt in February 2001 ( $\mathrm{n}=$ 24) and $22.9^{\circ} \mathrm{C}$ and 30.2ppt in July 2001 ( $\mathrm{n}=24$; Joyeux and colleagues, unpublished data).

Genera of the families Centropomidae (snook) and Mugilidae (mullet) were chosen as they belong to well differentiated trophic groups, are relatively abundant in the estuary, and attain a large size propitious to the detection of metal accumulation (Carvalho Filho, 1999). Snook are opportunistic top carnivores (i.e., secondary consumers) that tend to primarily prey on fish in the water column, including mullets, and secondarily on benthic macrocrustaceans (Marshall, 1958; Carter et al., 1973; Seaman and Collins, 1983; Teixeira, 1997). The two species present in our samples were the common snook Centropomus undecimalis (Bloch 1792), and the fat snook Centropomus parallelus Poey 1860. Feeding habits of the two species are similar. Grey mullets are essentially detritivorous fishes that complete their diet with macroalgae, microphytobenthos and small invertebrates caught on the bottom (Drake et al., 1984; Cardona, 2001). Our samples contained three species of these primary consumers: Mugil liza Valenciennes 1836, Mugil gairmardianus (Desmarest 1831) and Mugil platanus Günther 1880. Subsistence and local consumption are generally based on cheapness and 
abundance of the resource. It can be assumed that in Vitória Bay (as elsewhere, see Hanazaki, 2001), migrating mullet are much more consumed than snook by local populations, particularly during their estuarine residence period (summer).

In February 2001 (austral summer, rainy season) and July 2001 (austral winter, dry season), 10 fishes of each genus were acquired from subsistence fishermen that land their catch in Ilha das Caieiras (Fig. 1). Fishermen were interviewed to ascertain that each fish was caught in the central portion of the bay, close to the landing area. The boats used were generally unpowered, providing further assurance of the specimens origin. Fishes were identified, measured (total length $\pm 0.5 \mathrm{~cm}$ ) and weighted (wet weight $\pm 1 \mathrm{~g}$ ). All materials and recipients were descontaminated with $5 \% \mathrm{HNO}_{3}$. From each fish, two replicates of trunk white muscle were extracted, placed in plastic bags and frozen. Prior to analysis, replicates were left to thaw at ambient temperature. Approximately $3 g$ of flesh was extracted from each replicate and weighted with a digital balance of $0.001 \mathrm{~g}$ precision. Samples were added in teflon bombs with $5 \mathrm{~mL}$ nitric acid and were digested in microwave oven. The resulting solution was completed to $25 \mathrm{~mL}$ with de-ionized water (Amaral, 1989). Water content determination was conducted by drying selected samples in $100^{\circ} \mathrm{C}$ oven until constant weight (Mo and Neilson, 1994).

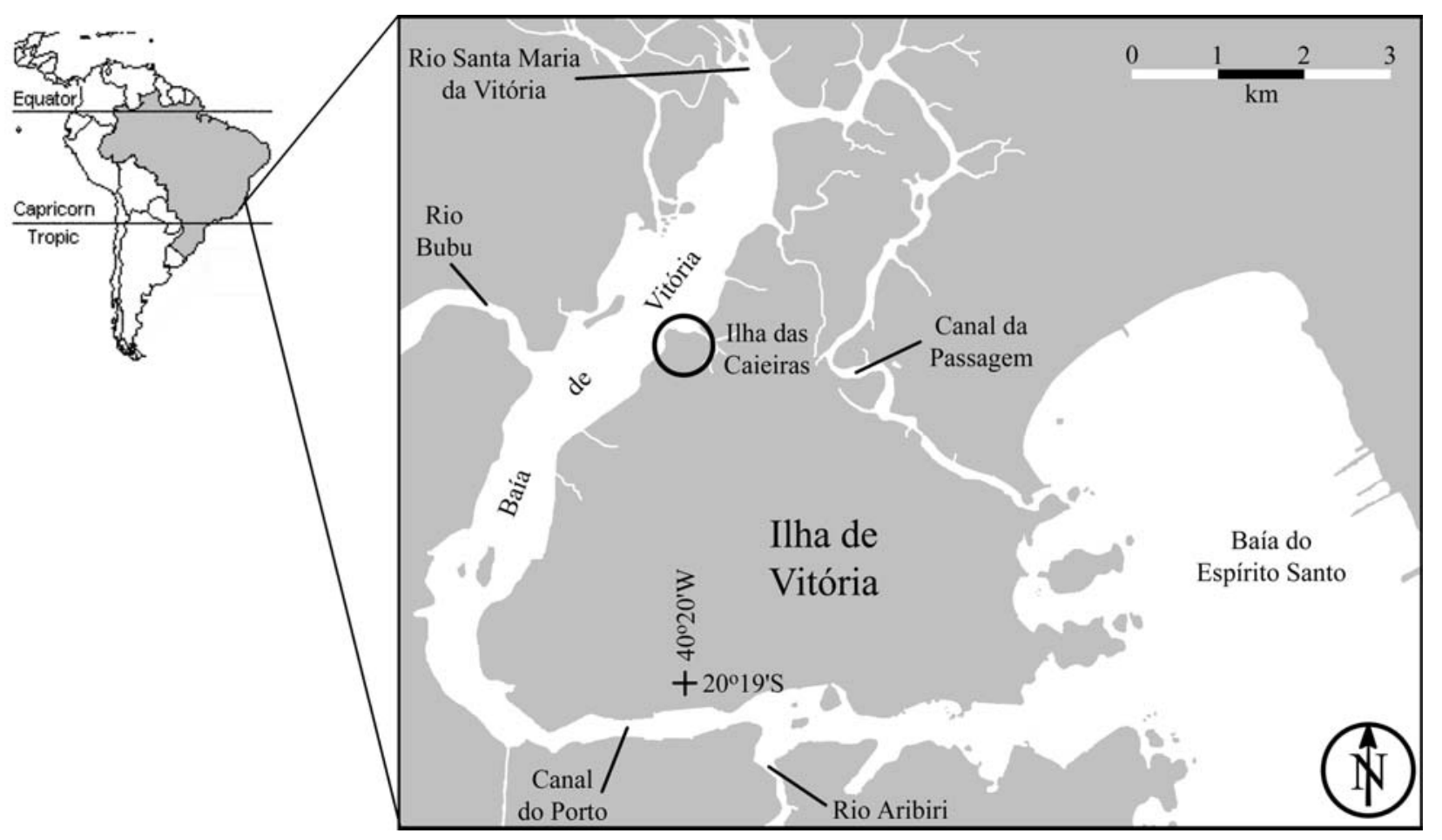

Figure 1 - Localization and principal features of the estuarine system of Vitória Bay, ES, Brazil. The state capital is located on the island (Ilha de Vitória). The system communicates to the Atlantic Ocean through two channels that open in the bay on the lower right (Baía do Espírito Santo). The landing site (Ilha das Caieiras) for subsistence fishermen that capture their catch in the central portion of the bay is indicated.

Samples were analyzed for $\mathrm{Zn}$ and $\mathrm{Cu}$ by flame atomic absorption spectrometry (model PerkinElmer 5100), and for $\mathrm{Cd}, \mathrm{Pb}$ and $\mathrm{Cr}$ by graphite furnace atomic absorption spectrometry (model Varian 1475 Gemini). Analyses were certified with replicated $0.75 \mathrm{~g}$ samples of the dry reference materials DORM-2 ('dogfish (Squalus acanthias) muscle', National Research Council of Canada) and MA-A-2 ('fish flesh homogenate', International Atomic Energy Agency) digested in microwave oven in $5 \mathrm{~mL}$ nitric acid and completed to $25 \mathrm{~mL}$ with de-ionized water. Two readings of each reference material or replicate were done, and the resulting mean was used in the statistical analyses. All results were expressed in $\mathrm{mg} \mathrm{g}^{-1}$ wet weight, excluding for the reference material. 
Dependent variables (length, weight, and metal concentrations) were tested for normality (Kolmogorov-Smirnov-Lilliefors test; Legendre and Legendre, 1983). Non-normal variables were transformed prior to inclusion in statistical models. Significance level $(\alpha)$ was set to 0.05 . When the transformed variable did not meet the assumptions for normality, $\alpha=0.01$ was used. Analyses of variance were carried out to detect differences in trace metal concentration between the two seasons and the two genera. The model of ANOVA with repeated measures was considered appropriate since two replicates were collected from each fish (Zar, 1999). The statistical analyses were run on SPSS (SPSS, Inc., 1989).

\section{RESULTS}

\section{Reference material}

Overall, few discrepancies were detected between analyzed and certified concentrations in the reference materials (Table 1). Standard recovery for DORM-2 and MA-A-2 varied 109\% for Cd, 79-108\% for $\mathrm{Cr}, 97-100 \%$ for $\mathrm{Cu}, 92-123 \%$ for $\mathrm{Pb}$ and $105-109 \%$ for $\mathrm{Zn}$. According to the reference materials tolerance limits or standard error, all major discrepancies occurred with DORM-2: Cd concentration was estimated slightly high in February and July, Cr low in July, and $\mathrm{Pb}$ high in February. The reference material MA-A-2 was found more appropriate than DORM-2 due to $\mathrm{Cr}$ and $\mathrm{Pb}$ concentrations closer to those from the fish samples.

\section{Trace metal concentrations}

Mean concentrations (non-transformed data) for the two sampling periods and the two genera are given in Table 2. At first glance, there were no obvious differences between February and July samples. Zinc varied between genera, and snook presented a mean concentration almost two times higher than that of mullet, although with a large standard deviation. No such difference was readily apparent for the other metals. Dry weight concentrations can be obtained by multiplying the wet weight concentrations used throughout the present study by 4.31 for snook (76.8\% water) and 4.03 for mullet ( $75.2 \%$ water).

Table 1 - Certified metal concentration in reference material and results of analyses, in $\mu \mathrm{g} \mathrm{g}^{-1}$ dry weight. Uncertainties represent 95 percent tolerance limits for an individual sample (DORM-2) or the standard error of the mean value (MA-A-2). Results of analyses are the mean of two replicates with dual lecture. Values were rounded off the same decimal than the certified value or to the precision limit of the technique utilized $(*)$.

\begin{tabular}{lrrrrr}
\hline \multicolumn{1}{c}{ Reference } & \multicolumn{5}{c}{ Values } \\
\hline \multicolumn{1}{c}{ DORM-2 } & $\mathbf{C d}$ & $\mathbf{C r}$ & $\mathbf{C u}$ & $\mathbf{P b}$ & \multicolumn{1}{c}{$\mathbf{Z n}$} \\
\hline \multirow{2}{*}{ Certified value } & 0.043 & 34.7 & 2.34 & 0.065 & 25.6 \\
Analyzed value (February) & $( \pm 0.008)$ & $( \pm 5.5)$ & $( \pm 0.16)$ & $( \pm 0.007)$ & $( \pm 2.3)$ \\
Analyzed value (July) & 0.047 & 29.3 & 2.28 & $0.08^{*}$ & 26.9 \\
\hline \multicolumn{1}{c}{ MA-A-2 } & 0.047 & 27.5 & 2.35 & $0.06^{*}$ & \multicolumn{1}{c}{27.5} \\
\hline Certified value & $\mathbf{C d}$ & $\mathbf{C r}$ & $\mathbf{C u}$ & $\mathbf{P b}$ & \multicolumn{1}{c}{$\mathbf{Z n}$} \\
Analyzed value (July) & 0.066 & 1.3 & 4.0 & 0.58 & 33 \\
& $( \pm 0.004)$ & $( \pm 0.1)$ & $( \pm 0.1)$ & $( \pm 0.07)$ & $( \pm 1)$ \\
\end{tabular}

\section{Normality and data transformation}

The normality tests on metal concentrations $(n=$ 40 in all cases) revealed that the distributions of four of the five metals were significantly different from normal $(\mathrm{p}=0.021$ for $\mathrm{Cd}$, and $\mathrm{p} \leq 0.001$ for $\mathrm{Cr}, \mathrm{Cu}$, and $\mathrm{Zn})$. Only $\mathrm{Pb}$ concentrations were normally distributed $(\mathrm{p} \geq 0.200)$. Quadratic $[\mathrm{Cd}$ (transformed) $\left.=\mathrm{Cd}^{2}\right]$ and logarithmic $\left[\mathrm{Zn}\right.$ (transformed) $\left.=\log _{\mathrm{e}}(\mathrm{Zn} \quad-\quad 2.7)\right]$ transformations succeeded in normalizing the distributions of $\mathrm{Cd}$ and $\mathrm{Zn}(\mathrm{p} \geq 0.200$, and $\mathrm{p}=$ 0.070 for $\mathrm{Cd}$ e $\mathrm{Zn}$, respectively). After logarithmic transformations $[\mathrm{Cr}$ (transformed $)=\log (\mathrm{Cr}$ 0.095); $\mathrm{Cu}$ (transformed) $=$ loge $(\mathrm{Cu}-0.104)]$, the distributions of $\mathrm{Cr}$ and $\mathrm{Cu}$ remained non-normal (p $=0.018$, and $\mathrm{p}=0.031$, respectively). Length presented normal distribution in the two genera ( $\mathrm{n}$ $=20$ and $\mathrm{p} \geq 0.200$ for both snook and mullet), 
contrarily to the wet weight $(\mathrm{p}=0.021$ and $\mathrm{p}=$ 0.020 for snook and mullet, respectively, with $\mathrm{n}=$ 20). Neither variable was transformed.

\section{Size concentration relationships}

Sampled snooks were $19-70 \mathrm{~cm}$ long, with weight varying between 68 and 3550g. Mullets were smaller $(18-50 \mathrm{~cm})$ and lighter $(55-905 \mathrm{~g})$. Concentrations of $\mathrm{Cd}, \mathrm{Cr}, \mathrm{Cu}$ and $\mathrm{Zn}$ were significantly and positively correlated with snook length (Table 3 and Figure 2). Significant correlations were also evidenced between $\mathrm{Cu}$ and $\mathrm{Zn}$ concentrations and wet weight (Table 3). A significant and negative correlation was detected in mullet between $\mathrm{Cr}$ concentration and length (Table 3 and Figure 2).

\section{Variation between seasons and genera}

No significant differences between replicates were detected by the within-subject tests (Table 4). The significant interactions Replicate*Season for $\mathrm{Ca}$ resulted from a higher variability between replicates in July, the second replicate being lower than the first. In the case of $\mathrm{Pb}$, the interaction Replicate*Season indicated the first replicate to be significantly lower than the second in February, while the opposite occurred in July.

Table 2 - Mean and extreme concentrations in trace metal in fish from Baía de Vitória, ES, in $\mu g^{-g^{-1}}$ wet weight, according to the sampling period and genus. The two replicates from each specimen were used $(\mathrm{n}=40$ for all metals). s.d. : standard deviation.

\begin{tabular}{|c|c|c|c|c|c|c|}
\hline & Statistics & Cd & $\mathrm{Cr}$ & $\mathrm{Cu}$ & $\mathbf{P b}$ & $\mathbf{Z n}$ \\
\hline \multirow{3}{*}{ February } & $\begin{array}{l}\text { Mean } \\
( \pm \text { s.d. })\end{array}$ & $\begin{array}{r}0.031 \\
\pm 0.005\end{array}$ & $\begin{array}{r}0.143 \\
\pm 0.134\end{array}$ & $\begin{array}{r}0.235 \\
\pm 0.081\end{array}$ & $\begin{array}{r}0.29 \\
\pm 0.06\end{array}$ & $\begin{array}{r}4.37 \\
\pm 1.80\end{array}$ \\
\hline & Minimum & 0.020 & 0.121 & 0.110 & 0.09 & 2.80 \\
\hline & Maximum & 0.039 & 0.179 & 0.390 & 0.41 & 8.08 \\
\hline \multirow{3}{*}{ July } & $\begin{array}{l}\text { Mean } \\
( \pm \text { s.d. })\end{array}$ & $\begin{array}{r}0.024 \\
\pm 0.008\end{array}$ & $\begin{array}{r}0.168 \\
\pm 0.071\end{array}$ & $\begin{array}{r}0.240 \\
\pm 0.112\end{array}$ & $\begin{array}{r}0.21 \\
\pm 0.04\end{array}$ & $\begin{array}{r}5.04 \\
+2.99\end{array}$ \\
\hline & Minimum & 0.010 & 0.097 & 0.133 & 0.14 & 2.95 \\
\hline & Maximum & 0.040 & 0.410 & 0.526 & 0.30 & 13.54 \\
\hline \multirow{3}{*}{ Snook } & $\begin{array}{l}\text { Mean } \\
( \pm \text { s.d. })\end{array}$ & $\begin{array}{r}0.026 \\
\pm 0.008\end{array}$ & $\begin{array}{r}0.160 \\
\pm 0.068\end{array}$ & $\begin{array}{r}0.261 \\
\pm 0.120\end{array}$ & $\begin{array}{r}0.23 \\
\pm 0.07\end{array}$ & $\begin{array}{r}6.14 \\
+2.83\end{array}$ \\
\hline & Minimum & 0.010 & 0.097 & 0.110 & 0.09 & 2.84 \\
\hline & Maximum & 0.039 & 0.410 & 0.526 & 0.37 & 13.54 \\
\hline \multirow{3}{*}{ Mullet } & $\begin{array}{l}\text { Mean } \\
( \pm \text { s.d. })\end{array}$ & $\begin{array}{r}0.030 \\
\pm 0.005\end{array}$ & $\begin{array}{r}0.151 \\
\pm 0.027\end{array}$ & $\begin{array}{r}0.214 \\
\pm 0.059\end{array}$ & $\begin{array}{r}0.27 \\
\pm 0.06\end{array}$ & $\begin{array}{r}3.26 \\
\pm 0.35\end{array}$ \\
\hline & Minimum & 0.020 & 0.106 & 0.153 & 0.15 & 2.80 \\
\hline & Maximum & 0.040 & 0.210 & 0.371 & 0.41 & 4.26 \\
\hline
\end{tabular}

Chromium and copper concentrations did not vary between genera or seasons (Table 4; see also Table 2). Mullet presented higher concentrations of $\mathrm{Cd}$ and $\mathrm{Pb}$, and lower of $\mathrm{Zn}$, than snook. Cadmium and lead concentrations were highest in February (Tables 2 and 4). The interaction Genus*Season in the ANOVA for Cd showed the concentrations to be approximately equal in the two genera in February, and significantly higher in mullet than in snook in July.

\section{DISCUSSION}

Variation of concentration between replicates was small, but readily apparent in two cases for snook (i.e., $\mathrm{Cr}$ and $\mathrm{Cu}$; see Figure 2). Such variation could be related to the exact nature of the sampled tissue (i.e., a possible contamination by a small proportion of red muscle) and amplified by the logarithm transformation applied to the data. This observation emphasizes that the intra-individual variability is important and that consumption may affect differently humans and other piscivores. These generally consume their prey whole, and 
may be contaminated by organs (gills, bones, liver, spleen, etc) that specifically accumulate metals (see for example Wood and Van Vleet, 1996, and Parsons, 1999).

None of the metals analyzed in the present study has been reported as being commonly bioaccumulated (e.g., Miramand et al., 1998; but see $\mathrm{Ni}$ et al., 2000) and, in fishes, metal levels generally diminish from the bottom (i.e., mullet, as primary consumers) to the top of the food chain (i.e., snook, as secondary consumers)(Mance, 1987). Our study showed little evidence for such phenomena (Tables 2 and 4) or its opposite (i.e., bioaccumulation). With the exception of $\mathrm{Zn}$, our results strongly contrast with that of Fernandes et al. (1994), who demonstrated that $\mathrm{Cu}$ and $\mathrm{Cr}$ are higher and $\mathrm{Zn}$ lower in the edible parts of mullet (Mugil sp.) than of snook (Centropomus sp.) caught in a lagoon in Rio de Janeiro.Frequently, concentrations decrease with age and size of the organisms because contamination does not always happen through ingestion but through contact across a permeable membrane such as the gill (Mance, 1987). Contact between fish and contaminating water (the ratio between surface and volume) decreases when the individual grows. Such lowering of the concentration with size was evidenced for $\mathrm{Cr}$ in mullet. However, positive correlations were found between $\mathrm{Cd}, \mathrm{Cr}, \mathrm{Cu}$ and $\mathrm{Zn}$ and size or weight of snook. The concatenation of different species within each genus could have masked (or enhanced) size-concentration relationships. Alternatively, restricted range of size and weight could have impeded the detection of a correlation with the concentration of $\mathrm{Cd}, \mathrm{Cu}, \mathrm{Pb}$ and $\mathrm{Zn}$ in mullet. Ninety-five percent of mullet were $36 \mathrm{~cm}$ and $398 \mathrm{~g}$ or less (the largest was $50 \mathrm{~cm}$ and $905 \mathrm{~g}$ ), while snook reached $70 \mathrm{~cm}$ and $3550 \mathrm{~g}$. More probably, increase or decrease (or absence of relationship) of metal concentration with size in a particular environment is both metal-specific and taxa-specific (e.g., Mears and Eisler, 1977).

Temporal variations in trace metal concentrations are frequently attributed to the effects of seasonality. That the observed variation (Table 4) could be related to seasonal diet changes was out of the scope of this study. Actually, there is no information on ontogenetic shift in diet, spatial distribution and population biology of the studied taxa and of their preferential preys within the estuarine system. Metal contamination in the biotic (i.e., Saraiva, 2000; present study) and abiotic compartiments of Vitória Bay are poorly known. Philips (1980) noted that in fish highest concentrations are generally observed by the end of winter and beginning of spring (slow growth period) and lowest concentrations by the end of summer (fast growth period). However, $\mathrm{Cd}$ and $\mathrm{Pb}$ concentrations in fishes from Vitória Bay were significantly higher in February (summer) than in July (winter) (Table 4). The bay presents accentuated variations in its physico-chemical characteristics, and the water is typically colder and saltier during the winter. Entry of nonbioaccumulating metals in organisms is generally correlated positively with temperature (through increase in the rate of metabolism) and negatively with salinity (Mance, 1987).

Table 3 - Linear correlation $(r=$ Pearson coefficient) between metal concentration (transformed data) and biometrics of the two genera. The two replicates from each fish were used $(\mathrm{n}=40$ for all metals). $P$ : probability; n.s. $=$ not significant.

\begin{tabular}{clcccc}
\hline \multirow{2}{*}{ Metal } & \multicolumn{2}{c}{ Length (cm) } & \multicolumn{2}{c}{ Weight (g) } \\
\cline { 3 - 6 } Snook & r & $\boldsymbol{P}^{*}$ & \multicolumn{2}{c}{$\boldsymbol{P}_{* *}$} \\
\hline \multirow{4}{*}{ Mullet } & Cadmium & 0.343 & 0.030 & 0.328 & n.s. \\
& Chromium & 0.332 & n.s. & 0.396 & n.s. \\
& Copper & 0.644 & $<0.001$ & 0.647 & $<0.001$ \\
& Lead & 0.075 & n.s. & 0.014 & n.s. \\
& Zinc & 0.573 & $<0.001$ & 0.588 & $<0.001$ \\
\hline & Cadmium & 0.140 & n.s. & -0.028 & n.s. \\
& Chromium & -0.498 & 0.001 & -0.316 & n.s. \\
& Copper & -0.217 & n.s. & -0.241 & n.s. \\
& Lead & 0.233 & n.s. & 0.166 & n.s. \\
& Zinc & -0.034 & n.s. & -0.066 & n.s. \\
\hline
\end{tabular}

* at the significance level $\alpha=0.05$ for $\mathrm{Cd}$. $\mathrm{Pb}$ and $\mathrm{Zn}$; at level $\alpha=0.01$ for $\mathrm{Cr}$ and $\mathrm{Cu}$. ** : at the significance level $\alpha=0.01$. 
SNOOK
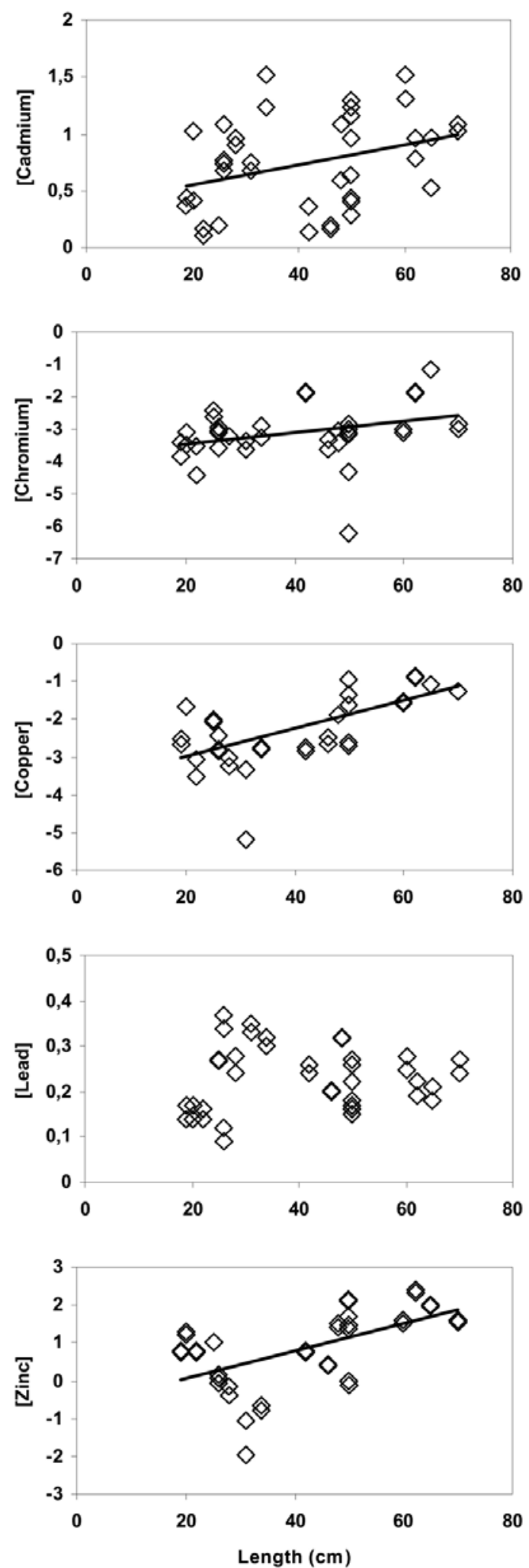

MULLET
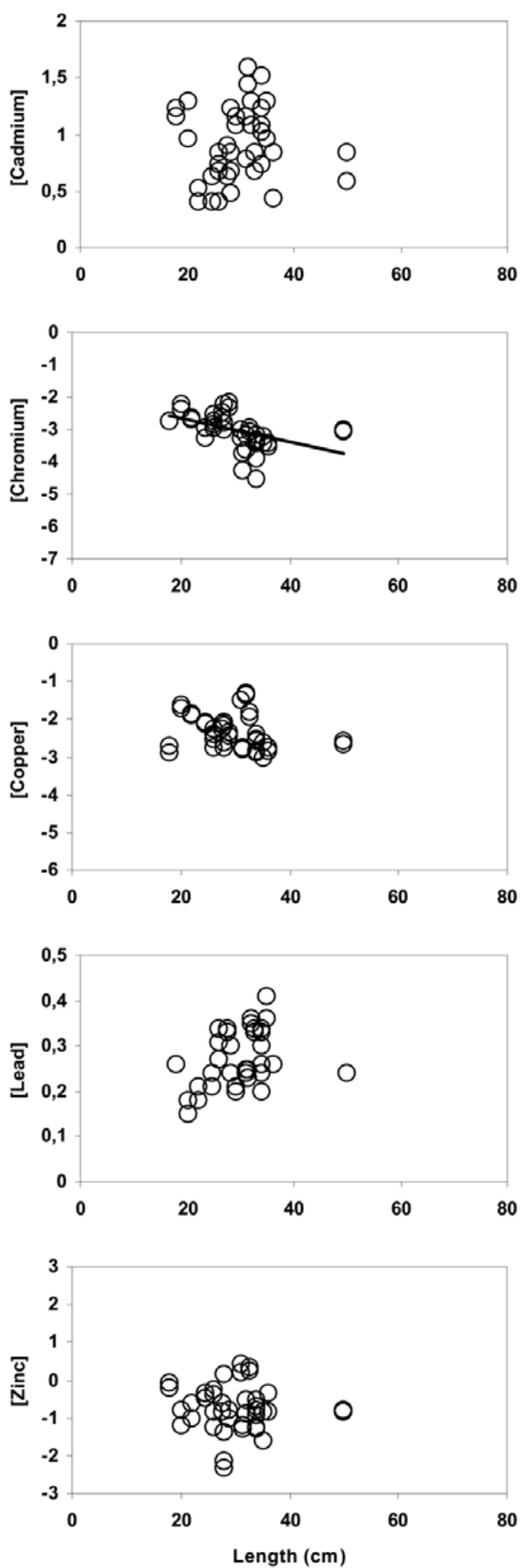

Figure 2 - Trace metal concentration in fish muscular tissue as a function of size in snook $(\diamond)$ and mullet $(\bigcirc)$ from Vitória Bay, ES. Concentration values were transformed as indicated in the text with transformed chromium concentration $\mathrm{x} 10^{3}$ ). Significant regression lines were overlaid to the data (see Table 3). 
Table 4 - Statistics for the analyses of variance (repeated measures) realized on trace metal concentrations in snook and mullet from Baía de Vitória, ES. $P$ : probability; n.s. = not significant.

\begin{tabular}{|c|c|c|c|c|c|c|}
\hline \multirow{2}{*}{ Source } & \multirow{2}{*}{$\begin{array}{c}\text { Degrees of } \\
\text { freedom }\end{array}$} & \multicolumn{5}{|c|}{$P *$} \\
\hline & & Cd & $\mathrm{Cr}$ & $\mathbf{C u}$ & $\mathbf{P b}$ & $\mathbf{Z n}$ \\
\hline \multicolumn{7}{|l|}{ Within-subject } \\
\hline Replicate & 1 & n.s. & n.s. & n.s. & n.s. & n.s. \\
\hline Replicate*Genus & 1 & n.s. & n.s. & n.s. & n.s. & n.s. \\
\hline Replicate*Season & 1 & 0.041 & n.s. & n.s. & 0.018 & n.s. \\
\hline Replicate*Genus*Season & 1 & n.s. & n.s. & n.s. & n.s. & n.s. \\
\hline Error & 36 & & & & & \\
\hline \multicolumn{7}{|l|}{ Among-subjects } \\
\hline Intercept & 1 & $<0.001$ & $<0.001$ & $<0.001$ & $<0.001$ & n.s. \\
\hline Genus & 1 & 0.042 & n.s. & n.s. & 0.017 & $<0.001$ \\
\hline Season & 1 & $<0.001$ & n.s. & n.s. & $<0.001$ & n.s. \\
\hline Genus*Season & 1 & 0.008 & n.s. & n.s. & n.s. & n.s. \\
\hline Error & 36 & & & & & \\
\hline
\end{tabular}

* at the significance level $\alpha=0.05$ for $\mathrm{Cd}$. $\mathrm{Pb}$ and $\mathrm{Zn}$; at level $\alpha=0.01$ for $\mathrm{Cr}$ and $\mathrm{Cu}$.

Winter conditions limiting metal entry or summer conditions favoring entry could be reflected in the observed variation of concentration of $\mathrm{Cd}$ and $\mathrm{Pb}$ in muscular tissues. This hypothesis, however, is not satisfactory in relation to $\mathrm{Cr}, \mathrm{Cu}$ and $\mathrm{Zn}$ that did not present seasonal variation (Table 4).

Few studies on metal contamination in fish muscular tissue from Brazilian estuaries have been published. Pfeiffer et al. (1985) reported extremely high contamination levels in mullet (Mugil sp.) from Sepetiba Bay (state of Rio de Janeiro). In this study, all fishes were captured in a single season (summer 1982/83). Chromium, copper, lead and zinc concentrations were two to three times higher than in Vitória Bay presently. Cadmium was the exception, with a contamination level equivalent to that found in the present study. Analyses on Mugil liza (and other estuarine fishes) caught in summer and fall 2000 recently evidenced a steep deterioration since that time (de Souza Lima et al., 2002). As can be determined from the figures, $\mathrm{Cr}$ concentration in gonads was 4-7 times higher than in muscle, but concentrations of other metals $(\mathrm{Cd}$, $\mathrm{Cu}, \mathrm{Pb}$ and $\mathrm{Zn}$ ) were similar in both tissues. Eysink et al. (1990) studied the biotic compartments of the estuarine system of IguapeCananéia (states of São Paulo and Paraná). All samples were collected in October 1986 (spring). Mean concentration in mullet (Mugil curema) muscle tended to be higher than in Vitória Bay for $\mathrm{Cu}$ and $\mathrm{Zn}$, and lower for $\mathrm{Pb}$, dependent of the sampling location. Liver concentrations were up to $4(\mathrm{~Pb}), 80(\mathrm{Cu})$ and $10(\mathrm{Zn})$ times higher than in muscle. All studies emphasized the threat of trace metals to human health.

In Brazil, maximum metal concentrations in food have been regulated since 1965 (Decree 55.87165, published 27/03/1965). Limits in seafood were established at $1 \mu \mathrm{g} \cdot \mathrm{g}^{-1}$ wet weight for $\mathrm{Cd}, 30$ for $\mathrm{Cu}, 0.1$ for $\mathrm{Cr}, 50$ for $\mathrm{Zn}$ and 2 for $\mathrm{Pb}$. These limits were reaffirmed several times for $\mathrm{Cd}$ and $\mathrm{Pb}$, including in international treaties (e.g., Mercosul/GMC Resolution 102-94), and by the Ministry of Health (Decision 685-98, published 28/08/1998 and 24/09/1998). In snook and mullet from Vitória Bay, only Cr concentrations appeared consistently over the legal limit (Table 2). However, consequences on human health from fish muscular tissue consumption are not expected since $\mathrm{Cr}$ is especially toxic under its ionic form 6+ (hexavalent) while most of $\mathrm{Cr}$ fixed in biota is under the form 3+ (FDA, 1993c). In fact, $\mathrm{Cr}$ is not one of the metals described in the Environmental Health Criteria series (EHC), nor in the Poisons Information Monographs (PIMS) published by the International Program of Chemical Safety (IPCS) of the World Health Organization (WHO). However, levels of $\mathrm{Pb}$ could be of concern. Acceptable intake suggested by FAO/WHO (1987) is $25 \mu \mathrm{g} \mathrm{kg}^{-1}$ per week for children, which correspond approximately to $200 \mathrm{~g}$ of fish per day for a child of $15 \mathrm{~kg}$. More strictly, FDA (1993b) suggested a maximum intake of $6 \mu \mathrm{g}$ per day for children under the age of six, ie. about $25 \mathrm{~g}$ of muscular tissue from snook or mullet caught in the bay. Both agencies defined higher limits for adults, 
respectively $50 \mu \mathrm{g} \mathrm{kg}^{-1}$ per week and $75 \mu \mathrm{g}$ per day. A (good?) point is that larger fish do not appear to present higher health concern than smaller ones (Figure 2 and Table 3). In another hand, summer concentrations were $138 \%$ those of winter and mullet concentrations were $117 \%$ those of snook (Table 2 and Table 4). These findings indicated that health risks could be significantly higher for cheaper subsistence fish (mullet) during high abundance and high demand periods (ie., summer)(cf., Hanazaki, 2001).

\section{ACKNOWLEDGEMENTS}

We thank Luis Felipe Max Niencheski (Fundação Universidade do Rio Grande), RS, Brazil) for reading the manuscript. We gratefully acknowledge the assistance of Companhia Vale do Rio Doce (Laboratory of Chemistry) and Companhia Siderúrgica de Tubarão (Environment Laboratory) for the technical help and the use of their equipment and reageants.

\section{RESUMO}

Tecidos musculares de tainhas (Mugil sp.) e robalos (Centropomus sp.) foram analisados por espectrometria de absorção atômica para determinar as concentrações dos metais cádmio, cromo, cobre, chumbo e zinco no músculo e avaliar os riscos a saúde humana resultante do consumo do pescado. Todos os indivíduos foram capturados por pescadores de subsistência na Baía de Vitória, um estuário brasileiro com numerosos lançamentos de efluentes não tratados de origem doméstica e industrial. Baseado na presunção que pescador de subsistência e consumidor local mostram pouca preferência (culinária ou outra) dentro de cada desses taxa, análises foram conduzidas, e resultados reportados, para gêneros em vez de espécies. Em robalos, as concentrações de cádmio, cromo, cobre e zinco aumentaram significativamente com o tamanho ou o peso. Em tainhas, o cromo diminuiu com o comprimento. Maiores teores de cádmio e chumbo e menores de zinco foram encontrados em tainhas que em robalos. Os teores de cádmio e chumbo foram significativamente mais altos em fevereiro (verão) que em julho (inverno). Cromo apresentou concentração acima dos teores admissíveis pela legislação brasileira em frutos do mar. Porém, o maior risco à saúde está provavelmente relacionado à concentração em chumbo, especialmente em relação ao consumo de pescado por crianças.

\section{REFERENCES}

Amaral, O. L. C. (1989), Estudo sobre o nível de concentração de $\mathrm{Cd}$, Pb e $\mathrm{Hg}$ nas águas, sedimentos e sururu (Mytella falcata) da Lagoa de Mundaú, Maceió - AL. M.Sc. Thesis (Chemistry), Pontifícia Universidade Católica do Rio de Janeiro, RJ, Brazil.

Blackmore, G. (2000), Field evidence of metal transfer from invertabrate prey to an intertidal predator, Thais clavigera (Gastropoda: Muricidae). Estuarine Coastal and Shelf Science, 51, 127-139.

Cardona, L. (2001), Non-competitive coexistence between Mediterranean grey mullet: evidence from seasonal changes in food avalability, niche breath and trophic overlap. J. Fish Biology, 59 : (3), 729-744.

Carter, M. R.; Burns, L. A.; Cavinder, T. R.; Dugger, K. R.; Fore, P. L.; Hicks, D. B.; Revells, H. L. and Schmidt, T. W. (1973), Ecosystems analysis of the Big Cypress Swamp and estuaries. United States Environmental Protection Agency, PB-233 070.

Carvalho-Filho, A. (1999), Peixes: costa brasileira. São Paulo : Melro.

Chang, S.; Zdanowicz, V. S. and Murchelano, R. A. (1998), Association between liver lesions in winter flounder (Pleuronectes americanus) and sediment chemical contaminants from northeast United States estuaries. ICES J. Marine Science, 55, 954-969.

DelValls, T. A.; Blasco, J.; Sarasquete, M. C.; Forja, M. J. and Gomez-Parra, A. (1998), Evaluation of heavy metal sediment toxicity in littoral ecosystems using juveniles of the fish Sparus aurata. Ecotoxicology and Environmental Safety, 41, 157-167.

Demayo, A. (1981), Cadmium. In: Guideline for surface water quality: inorganic chemical substances. Ottawa, Environmental Canada, 1.

Demayo, A.; Taylor, M. C. and Reeder, S. M. (1980), Lead. In: Guideline for surface water quality: inorganic chemical substances. Ottawa, Environmental Canada, 1.

Drake, P.; Arias, A. M. and Gállego, L. (1984), La biología de los mugílideos (Osteichthyes, Mugilidae) en los esteros de las salinas de San Fernando (Cádiz). III. Hábitos alimentarios y su relación con la morfometría del aparato digestivo. Investigaciones Pesqueras, 48, 337-367.

Eysink, G. G. J.; Martins, M. C.; Vargas-Boldrini, C. and Navas-Pereira, D. (1990) Metais pesados em organismos aquáticos do rio Ribeira de Iguape e do complexo estuarino-lagunar Iguape- Cananéia: avaliação preliminar. In: Simpósio de Ecossistemas da Costa Sul e Sudeste Brasileira, 2. Anais... pp. 417-443. 
Fernandes, H. M.; Bidone, E. D.; Veiga, L. H. S. and Patchineelam, S. R. (1994), Heavy metal pollution assessment in the coastal lagoons of Jacapaguá, Rio de Janeiro, Brazil. Environmental Pollution, 85, 259-264.

Food and Agriculture Organization/World Health Organization (1987), Expert comittee on food additives and contaminants. WHO Technical Reports Series, 751.

Food and Drug Administration (1993a), Guidance document for cadmium in shellfish. Center for food safety and applied nutrition, United States Food and Drug Administration. Washington, D.C.

Food and Drug Administration (1993b), Guidance document for lead in shellfish. Center for food safety and applied nutrition, United States Food and Drug Administration. Washington, D.C.

Food and Drug Administration (1993c), Guidance document for chromium in shellfish. Center for food safety and applied nutrition, United States Food and Drug Administration. Washington, D.C.

Hanazaki, N. (2001), Ecologia de caiçaras: uso de recursos e dieta. $\mathrm{PhD}$ Thesis (Ecology), Universidade Estadual de Campinas, SP, Brazil.

Joyeux, J.C. and Ward, A.B. (1998), Constraints on coastal lagoons fisheries. Advances in Marine Biology, 34, 73-178.

Laegdsgaard, P. and Johnson, C. (2000), Why do juvenile fish utilize mangrove habitats? J. Exp. Marine Biology and Ecology, 257 : (2), 229-253.

Legendre, L. and Legendre, P. (1983), Numerical Ecology. Elsevier, Amsterdam, The Netherlands.

Mance, G. (1987), Pollution threat of heavy metals in aquatic environments. New York : Elsevier.

Marshall, A. R. (1958), A survey of the snook fishery of Florida, with studies of the biology of the principal species, Centropomus undecimalis. State of Florida, State Board of Conservation, Technical Series, 22.

Mears, H. C. and Eisler, R. (1977), Trace metal in liver from bluefish, tautog and tilefish in relation to body lentgh. Chesapeake Science, 18 : (3), 315-318.

Miramand, P.; Fichet, D.; Bentley, D.; Guary, J. C. and Caurant, F. (1998), Concentrations em métaux lourds (cd, $\mathrm{Cu}, \mathrm{Pb}, \mathrm{Zn}$ ) observées le long du gradient de salinité dans le réseau trophique de l'estuaire de la Seine. Comptes-Rendus de l'Académie des Sciences de Paris, Sciences de la Terre et des Planètes, 327, 259-264.

Mo, C. and Neilson, B. (1994), Standardization of oyster soft tissue dry weight measurements. Water Research, 28 : (1), 243-246.

Ni, I. H., Wang, W. X. and Tam, Y. K. (2000), Transfert of $\mathrm{Cd}, \mathrm{Cr}$, and $\mathrm{Zn}$ from zooplankton prey to mudskipper Periophthalmus cantonensis and glassy Ambassis urotaenia fishes. Marine Ecology Progress Series, 194, 203-210.

Nixon, S. W. (1982), Nutrient dynamics, primary production and fisheries yields of lagoons. Oceanologica Acta, 4 : (suppl.), 357-371.
Nriagu, J. O. and Pacyna, J. M. (1988), Quantitative assessment of worlwide contamination for air, water and soil by trace metals. Nature, 333, 134-139.

Parsons, E. C. M. (1999), Trace element concentrations in whole fish from North Lantau waters, Hong Kong. ICES Journal of Marine Science, 56, 751-794.

Pfeiffer, W. C.; Lacerda, L. D.; Fiszman, M. and Lima, N. R. W. (1985), Metais pesados no pescado da Baía de Sepetiba, Estado do Rio de Janeiro. Ciência $e$ Cultura, 37 : (2), 297-302.

Philips, D. J. H. (1980), Quantitative aquatic biological indicators. London : Applied Science Publishers.

Plant, J.; Simth, D.; Smith, B. and Williams, L. (2001), Environmental geochemistry at the global scale. Applied Geochemistry, 16, 1291-1308.

Rainbow, P. S. (1985), The biology of heavy metals in the sea. International J. Environmental Studies, 21, 195-211.

Saraiva, E. M. S. (2000), Avaliação da contaminação por metais pesados ( $\mathrm{Cd}, \mathrm{Cr}, \mathrm{Cu}, \mathrm{Fe}, \mathrm{Ni}, \mathrm{Pb}$, e $\mathrm{Zn}$ ) no manguezal do Rio Santa Maria da Vitória - Grande Vitória/ES - utilizando Crassostrea rhizophorae (Guildins, 1828) e Mytella guyanensis (Lamarck, 1819) como bioindicadores. M.Sc. Thesis (Biology), Universidade Federal do Espírito Santo, ES, Brazil.

Seaman Jr., W., and Collins, M. (1983), Species profiles: life histories and environmental requirements of coastal fishes and invertabrates (South Florida) - snook. U.S. Fish and Wildlife Service, FWS/OBS-82/11.16. U.S. Army Corps of Engineers, TR EL-82-4.

Smith, W. E. and Smith, A. M. (1973), Minamata. New York : Holt, Rinehart and Winston.

Souza Lima, R. G.; Araújo, F. G.; Maia, M. F. and Pinto, A. S. S. B. (2002), Evaluation of heavy metals in fish of the Sepetiba and Ilha Grande Bays, Rio de Janeiro, Brazil. Envir. Research, Section A, 89, 171-179.

Statistical Package for the Social Sciences (1989), SPSS for Windows, release 7.0.

Teixeira, R. L. (1997), Distribution and feeding habits of the youg common snook, Centropomus undecimalis (Pisces: Centropomidae), in the shallow waters of a tropical Brazilian estuary. Boletim do Museu de Biologia Mello Leitão (Nova Série), 6, 35-46.

Ward, N. I. (1995), Trace elements. In: Fifield, F. W. and Haines, P. J. (Eds.). Environmental analytical chemistry. London : Blackie Academic and Professional. Chapman and Hall.

Wood, C. M. and Van Vleet, E. S. (1996), Copper, cadmium and zinc in liver, kidney and muscle tissues of bottlenose dolphins (Tursiops truncatus) stranded in Florida. Marine Pollution Bulletin, 32 : (12), 886-889.

Zar, J. H. (1999), Biostatistical analysis. $4^{\text {th }}$ ed. Upper Saddle River, NJ : Prenctice Hall.

Received: February 19, 2002; Revised: October 10, 2003; Accepted: May 13, 2004. 